\title{
PENDIDIKAN KESEHATAN DENGAN MEDIA VIDEO DAN MEDIA E BOOKLET MENINGKATKAN PENGETAHUAN PEMBERIAN MP-ASI
}

\author{
Wiji Lestari \\ Puskesmas Kekopan Dinkes Kota Magelang \\ email :weg2682@gmail.com
}

Riwayat Artikel: Diterima: 2 November 2021, direvisi: 25 November 2021, dipublikasi: 29 November 2021

\begin{abstract}
Mother's knowledge in giving complementary food for breast milk is very important considering that there are many mistakes in the practice of giving it, such as giving complementary food for breast milk too early before the age of 6 months. The purpose of this study was to determine the effectiveness of health education with video media and e-booklet media on knowledge about giving complementary feeding to mothers who have babies aged 6-12 months. This study uses a comparative analysis with quantitative methods and a Quasy Experimental research design consisting of two paired groups with a pre and post test Nonecquivalent without Control Group Design. The results of this study indicate that there is an effect of health education both with video media and ebooklet media on mother's knowledge about complementary food for breast milk with a $p$-value of 0.000. And it was found that the effectiveness of health education with video and ebooklet media was not significantly different with $p$-value $>0.05$. However, although it is not significantly more effective than video media, health education with video media is assessed from the mean rank difference between pre and post test scores of 37.33 which is higher than 33.93.
\end{abstract}

Keywords: Health education; video media; ebooklet media; knowledge of Complementary Food for Breast Milk.

\begin{abstract}
ABSTRAK
Pengetahuan ibu dalam pemberian MP-ASI sangat penting karena banyak terjadi kesalahan dalam praktik pemberian MP-ASI. Tujuan penelitian untuk mengetahui Efektifitas Pendidikan Kesehatan dengan Media Video dan Media E booklet Terhadap Pengetahuan Tentang Pemberian MP-ASI Pada Ibu Yang Mempunyai Bayi Usia 6-12 bulan. Desain penelitian Quasi Eksperiment terdiri dari dua grup berpasangan dengan pre and post test Nonecquivalent without Control Group Design. Analisa uji beda pre dan post menggunakan uji Wilcoxon. Sedangkan untuk menguji perbedaaan efektifitas pendidikan kesehatan dengan media video dan media e booklet yaitu uji Mann Whitney. Hasil penelitian ini menunjukan ada pengaruh pendidikan kesehatan baik dengan media video maupun media ebooklet terhadap pengetahuan ibu tentang MP-ASI dengan nilai p-value 0,000. Efektivitas pendidikan kesehatan dengan media video dan ebooklet tidak berbeda secara signifikan dengan hasil $p$-value $>0,05$. Meskipun tidak secara signifikan pendidikan kesehatan dengan media video lebih efektif dibanding media ebooklet dinilai dari mean rank selisih nilai pre dan post test 37,33 lebih tinggi dari 33,93.
\end{abstract}

Kata Kunci: Pendidikan kesehatan; media video; media ebooklet; pengetahuan tentang MP ASI 


\section{Pendahuluan}

Permasalahan gizi kurang hampir merata di setiap wilayah di Indonesia, tak terkecuali di Kota Magelang. Sebanyak 0,19\% atau 10 dari 5.340 balita ditimbang di Kota Magelang mengalami gizi buruk berdasarkan BB/TB, 25 balita (0,47\%) mengalami BGM, dan $397(7,43)$ balita mengalami gizi kurang underweight pada tahun 2019 (Dinas Kesehatan Kota Magelang, 2020) (Kementrian Kesehatan RI, 2020).

Menurut data cakupan tahun 2019 masih terdapat 10 balita gizi buruk di Kota Magelang dari total 1536 balita ditimbang $(0,65 \%)$, dan $80 \%$ dari balita gizi buruk di Kota Magelang adalah berasal dari wilayah kecamatan Magelang Tengah yaitu 8 balita gizi buruk dari total 10 balita gizi buruk di Kota Magelang (Dinas Kesehatan Kota Magelang, 2020).

Menurut data cakupan semester I tahun 2020 di wilayah kecamatan Magelang Tengah masih terdapat 71 balita gizi buruk dan gizi kurang dari 1469 balita yang ditimbang $(4,8 \%)$ sedangkan di wilayah kerja Puskesmas Kerkopan sendiri menunjukkan data gizi kurang sebanyak $6,37 \%$ (19) dari 298 balita pada bulan Agustus 2020 (Dinas Kesehatan Kota Magelang, 2020).

Selama ini, media yang digunakan oleh Puskesmas yaitu dengan buku KIA. Berdasarkan studi pendahuluan yang dilakukan diwilayah kerja Puskesmas Kerkopan, hasil yang diperoleh adalah dari 10 orangtua bayi yang diberikan kuesioner, 7 orang ibu (70\%) mengatakan bahwa dalam pemberian makanan pendamping $\mathrm{ASI}$ ibu memberikan dengan makanan instan dan selebihnya memberikan makanan bayinya dengan meracik sendiri dan makanan yang diberikan cenderung tidak bervariasi (Dinas Kesehatan Kota Magelang, 2020).

Edukasi dapat meningkatkan pengetahuan ibu dan jenis edukasi yang paling efektif adalah edukasi yang melibatkan indra pendengaran dan indra penglihatan seperti penyuluhan yang memanfaatkan media cetak (booklet, leaflet, poster dan lembar balik), penyuluhan dengan menggunakan audio visual, penyuluhan dengan film pendek, penyuluhan dengan demonstrasi, penyuluhan dengan metode presentasi, dan penyuluhan dengan menggunakan sosial media yang dimana pada handphone memiliki berbagai fitur yang dapat dimanfaatkan untuk melakukan edukasi (Muharram et al., 2021).

Penelitian mengetahui Efektifitas Pendidikan Kesehatan dengan Media Video dan Media $E$ booklet Terhadap Pengetahuan Tentang Pemberian MP-ASI Pada lbu Yang Mempunyai Bayi Usia 6-12 bulan perlu dilakukan di Kota Magelang, karena dibutuhkan strategi penyampaian pengetahuan yang sesuai kebutuhan masyarakat yang tidak memelukan tatap muka secara langsung. Penelitian sejenis sudah pernah dilakukan tetapi setiap wilayah memiliki karakteristik yang berbeda sehingga perlu disesuaikan dengan karakteristik masyarakat Kota Magelang untuk mendapatkan media yang paling sesuai.

\section{Metode Penelitian}

Jenis penelitian yang digunakan dalam penelitian ini adalah analisa komparatif dengan metode kuantitatif dan desain penelitian Quasi Eksperiment terdiri dari dua grup berpasangan dengan pre and post test Nonecquivalent without Control Group Design. Masing masing kelompok dinilai sebelum dan sesudah diberikan intervensi. Hal ini bertujuan untuk mengetahui tingkat efektifitas pendidikan kesehatan melalui media video dibandingkan dengan media e booklet.

Populasi penelitian ini adalah semua ibu yang mempunyai bayi usia 6-12 bulan pada bulan Januari 2021 di wilayah kecamatan Magelang Tengah Kota Magelang sebanyak 228 ibu. Pengambilan sampel dalam penelitian ini menggunakan tehnik non probability sampling dengan sampling insidental yaitu sampel diambil pada ibu yang kebetulan memeriksakan bayinya ke Puskesmas. Jumlah sampel yang diambil sebanyak 70 ibu dengan syarat telah memenuhi kriteria inklusi yang ditetapkan. Teknik pengumpulan data yang digunakan dalam penelitan melalui kuesioner.

Hasil uji normalitas data didapatkan hasil $p$ value $<0,05$ yang artinya data tidak berdistribusi normal. Untuk melakukan analisa uji hubungan pendidikan kesehatan dengan media video serta media e booklet pre dan post tes dengan menggunakan uji 
Wilcoxon. Sedangkan untuk menguji perbedaaan efektifitas pendidikan kesehatan dengan media video dan media e booklet yaitu untuk menguji dua kelompok tidak berpasangan adalah dengan menggunakan uji Mann Whitney.

\section{Hasil dan Pembahasan}

Intervensi pendidikan kesehatan melalui media video di sampaikan kepada responden dalam bentuk video power point yang diisi dengan penjelasan berupa audio dari narasumber dan dibagikan kepada responden melalui pesan whatsapp berupa link google drive. Sedangkan intervensi pendidikan kesehatan melalui media ebooklet disampaikan kepada responden berupa ebook bergambar sejumlah 23 halaman dan dibagikan kepada responden melalui pesan whatsapp berupa link anyflip.

Kuesioner yang digunakan dengan google form berupa pre dan post test yang disebarkan kepada responden melalui pesan whatsapp. Peneliti menyebarkan sebanyak 73 kuesioner dengan 3 responden dropout, dari 70 responden dibagi menjadi dua kelompok intervensi yaitu sebanyak 35 responden dengan intervensi media video dan 35 responden dengan intervensi media ebooklet.

Tabel 1 Distribusi pengetahuan ibu tentang pemberian MP-ASI bayi usia 6-12 bulan sebelum diberikan pendidikan kesehatan dengan media video

\begin{tabular}{|c|c|c|c|c|}
\hline \multirow[t]{2}{*}{ Variabel } & \multicolumn{4}{|c|}{$\begin{array}{c}\text { Kelompok Pendidikan } \\
\text { Kesehatan dengan Media } \\
\text { Video }\end{array}$} \\
\hline & Min & Max & Median & SD \\
\hline $\begin{array}{l}\text { Pengetahuan } \\
\text { sebelum }\end{array}$ & 35 & 95 & 80.00 & 15.056 \\
\hline
\end{tabular}

Pada tabel 1 ditampilkan distribusi tingkat pengetahuan ibu tentang MPASI pada nilai pre test dengan media video mempunyai rentang nilai antara 35 sebagai nilai terendah sampai dengan 95 sebagai nilai paling tinggi, nilai median yang didapatkan 80,00 dengan nilai SD 15.056.

Distribusi frekuensi tingkat pengetahuan ibu sebelum mendapat intervensi video ditampilkan pada tabel 2. Sebagian besar responden memiliki nilai lebih besar atau sama dengan nilai median yaitu sebanyak
19 orang $(54,3 \%)$ dan terdapat 2 orang responden $(5,7 \%)$ mendapat nilai kurang dari 50. Sedangkan nilai terbanyak yang diperoleh responden adalah 90 yaitu sebanyak 9 orang $(25,7 \%)$.

Tabel 2 Tingkat pengetahuan ibu tentang pemberian MP-ASI bayi usia 6-12 bulan sebelum diberikan pendidikan kesehatan dengan media video

\begin{tabular}{ccc}
\hline $\begin{array}{c}\text { Nilai Pretest media } \\
\text { video }\end{array}$ & Frekuensi & Persentase \\
\hline 35 & 1 & 2.9 \\
\hline 45 & 1 & 2.9 \\
\hline 55 & 3 & 8.6 \\
\hline 60 & 3 & 8.6 \\
\hline 65 & 1 & 2.9 \\
\hline 70 & 3 & 8.6 \\
\hline 75 & 4 & 11.4 \\
\hline 80 & 6 & 17.1 \\
\hline 85 & 2 & 5.7 \\
\hline 90 & 9 & 25.7 \\
\hline 95 & 2 & 5.7 \\
\hline Total & 35 & 100.0 \\
\hline
\end{tabular}

Tabel 3 Distribusi pengetahuan ibu tentang pemberian MP-ASI bayi usia 6-12 bulan sesudah diberikan pendidikan kesehatan dengan media video

\begin{tabular}{ccccc}
\hline \multicolumn{1}{c}{ Variabel } & \multicolumn{4}{c}{$\begin{array}{c}\text { Kelompok Pendidikan } \\
\text { Kesehatan dengan Media } \\
\text { Video }\end{array}$} \\
\hline & Min & Max & Median & SD \\
\hline $\begin{array}{l}\text { Pengetahuan } \\
\text { sesudah }\end{array}$ & 60 & 100 & 90.00 & 10.831 \\
\hline
\end{tabular}

Berdasarkan tabel 3, distribusi tingkat pengetahuan ibu tentang MPASI pada nilai post test dengan media video mempunyai rentang nilai antara 60 sampai dengan nilai tertinggi 100 , nilai median 90 dengan nilai SD 10.831.

Distribusi frekuensi tingkat pengetahuan ibu sesudah mendapat intervensi video ditampilkan pada tabel 4. adalah sebagian besar responden memiliki nilai lebih besar atau sama dengan nilai median yaitu sebanyak 18 orang $(51,4 \%)$ dan tidak ada responden yang mendapat nilai kurang dari 50. Nilai terbanyak yang diperoleh responden adalah 85,90 dan 100 atau masing-masing $20 \%$. 
Tabel 4 Tingkat pengetahuan ibu tentang pemberian MP-ASI bayi usia 6-12 bulan sesudah diberikan pendidikan kesehatan dengan media video

\begin{tabular}{ccc}
\hline $\begin{array}{c}\text { Nilai post test media } \\
\text { video }\end{array}$ & Frekuensi & Persentase \\
\hline 60 & 1 & 2.9 \\
\hline 65 & 1 & 2.9 \\
\hline 70 & 2 & 5.7 \\
\hline 75 & 4 & 11.4 \\
\hline 80 & 2 & 5.7 \\
\hline 85 & 7 & 20.0 \\
\hline 90 & 7 & 20.0 \\
\hline 95 & 4 & 11.4 \\
\hline 100 & 7 & 20.0 \\
\hline Total & 35 & 100.0 \\
\hline
\end{tabular}

Menurut Ahmadi menyatakan bahwa media video yaitu segala sesuatu yang memungkinkan sinyal audio dapat dikombinasikan dengan sebuah gambar bergerak secara sekuensal. Berdasarkan tabel 1 dan 3 , hasil yang didapat dari nilai pre test dengan media video mempunyai rentang nilai antara 35 sampai 95 dan nilai median 80 dengan nilai SD 15.056. Nilai post test dengan media video mempunyai rentang nilai antara 60 sampai 100 dan nilai median 90 dengan nilai SD 10.831 (Ahmadi \& Ibda, 2018).

Berdasarkan tabel 2, distribusi frekuensi tingkat pengetahuan ibu sebelum mendapat intervensi video adalah sebagian besar responden memiliki nilai lebih besar atau sama dengan nilai median yaitu sebanyak 19 orang $(54,3 \%)$ dan terdapat 2 orang responden $(5,7 \%)$ mendapat nilai kurang dari 50. Sedangkan nilai terbanyak yang diperoleh responden adalah 90 yaitu sebanyak 9 orang (25,7\%). Sedangkan berdasarkan tabel 4, distribusi frekuensi tingkat pengetahuan ibu sesudah mendapat intervensi video adalah sebagian besar responden memiliki nilai lebih besar atau sama dengan nilai median yaitu sebanyak 18 orang $(51,4 \%)$ dan tidak ada responden yang mendapat nilai kurang dari 50 . Nilai terbanyak yang diperoleh responden adalah 85,90 dan 100 atau masing-masing $20 \%$.

Berdasarkan hasil tersebut maka dapat disimpulkan rata-rata responden mempunyai pengetahuan yang baik dan meningkat setelah diberi intervensi. Hal tersebut menunjukkan bahwa tingkat pengetahuan responden sebelum mendapatkan intervensi pendidikan kesehatan dengan media video masih terdapat responden yang memiliki nilai pengetahuan dibawah 50 dan setelah mendapatkan intervensi pendidikan kesehatan mengalami peningkatan pengetahuan dimana seluruh responden tidak ada yang mendapat nilai dibawah 50 dari nilai median 80 menjadi 90 .

Tabel 5 Distribusi pengetahuan ibu tentang pemberian MP-ASI bayi usia 6-12 bulan sebelum diberikan pendidikan kesehatan dengan media ebooklet

\begin{tabular}{lcccc}
\hline \multirow{2}{*}{ Variabel } & \multicolumn{4}{c}{$\begin{array}{c}\text { Kelompok Pendidikan } \\
\text { Kesehatan dengan Media } \\
\text { Ebooklet }\end{array}$} \\
\cline { 2 - 5 } & Min & Max & Median & SD \\
\hline $\begin{array}{l}\text { Pengetahuan } \\
\text { sebelum }\end{array}$ & 55 & 100 & 80.00 & 10.568 \\
\hline
\end{tabular}

Pada tabel 5 distribusi nilai pre test responden kelompok intervensi dengan media ebooklet didapatkan rentang nilai dari 55 sampai dengan nilai tertinggi 100, nilai median adalah 80 dengan nilai SD 10,568 .

Tabel 6 Tingkat pengetahuan ibu tentang pemberian MP-ASI bayi usia 6-12 bulan sebelum diberikan pendidikan kesehatan dengan media ebooklet

\begin{tabular}{ccc}
\hline $\begin{array}{c}\text { Nilai pre test } \\
\text { media ebooklet }\end{array}$ & Frekuensi & Persentase \\
\hline 55 & 2 & 5.7 \\
\hline 60 & 1 & 2.9 \\
\hline 70 & 3 & 8.6 \\
\hline 75 & 9 & 25.7 \\
\hline 80 & 5 & 14.3 \\
\hline 85 & 8 & 22.9 \\
\hline 90 & 4 & 11.4 \\
\hline 95 & 1 & 2.9 \\
\hline 100 & 2 & 5.7 \\
\hline Total & 35 & 100.0 \\
\hline
\end{tabular}

Menurut tabel 6, distribusi frekuensi tingkat pengetahuan ibu sebelum mendapat intervensi dengan media ebooklet adalah sebagian besar responden memiliki nilai lebih besar atau sama dengan nilai median yaitu sebanyak 20 orang $(57,1 \%)$ dan tidak ada responden yang mendapat nilai kurang dari 50. Nilai terbanyak yang diperoleh responden adalah nilai 75 yaitu sebanyak 9 orang $(25,7 \%)$. 
Tabel 7 Distribusi pengetahuan ibu tentang pemberian MP-ASI bayi usia 6-12 bulan sesudah diberikan pendidikan kesehatan dengan media ebooklet

\begin{tabular}{|c|c|c|c|c|}
\hline \multirow[t]{2}{*}{ Variabel } & \multicolumn{4}{|c|}{$\begin{array}{l}\text { Kelompok Pendidikan } \\
\text { Kesehatan dengan Media } \\
\text { Ebooklet }\end{array}$} \\
\hline & Min & Max & Median & SD \\
\hline $\begin{array}{l}\text { Pengetahuan } \\
\text { sesudah }\end{array}$ & 60 & 100 & 90.00 & 9.947 \\
\hline
\end{tabular}

Distribusi nilai post test kelompok responden dengan intervensi media ebooklet ditampilkan pada table 7, didapatkan rentang nilai antara 60 sampai dengan nilai tertinggi 100 , nilai median 90 dengan nilai SD 9,947.

Tabel 8 Tingkat pengetahuan ibu tentang pemberian MP-ASI bayi usia 6-12 bulan sesudah diberikan pendidikan kesehatan dengan media ebooklet

\begin{tabular}{ccc}
\hline $\begin{array}{c}\text { Nilai post test media } \\
\text { ebooklet }\end{array}$ & Frequency & Percent \\
\hline 60 & 1 & 2.9 \\
\hline 65 & 1 & 2.9 \\
\hline 75 & 3 & 8.6 \\
\hline 80 & 4 & 11.4 \\
\hline 85 & 5 & 14.3 \\
\hline 90 & 10 & 28.6 \\
\hline 95 & 4 & 11.4 \\
\hline 100 & 7 & 20.0 \\
\hline Total & 35 & 100.0 \\
\hline
\end{tabular}

Berdasarkan tabel 8, sebagian besar responden memiliki nilai lebih besar atau sama dengan nilai median yaitu sebanyak 21 orang $(60 \%)$ dan tidak ada responden yang mendapat nilai kurang dari 50 . Nilai terbanyak yang diperoleh responden adalah nilai 90 yaitu sebanyak 10 orang (28,6\%).

Booklet yaitu media berbentuk buku (gambar ataupun tulisan) yang berguna untuk menyampaikan pesan kesehatan. Booklet yaitu buku kecil yang berisi maksimal 24 lembar dengan isi yang jelas, tegas dan mudah dimengerti (Suarioka \& Supariasa, 2012, pp. 30-31). Berdasarkan tabel 4.5 nilai pre test dengan media ebooklet mempunyai rentang nilai antara 55 sampai dengan 100 dan nilai median 80 dengan SD 10,568. Sedangkan berdasarkan tabel 7 nilai post test dengan media ebooklet didapatkan rentang nilai antara 60 sampai dengan 100 dan nilai median 90 dengan nilai SD 9,947.
Berdasarkan tabel 6, distribusi frekuensi tingkat pengetahuan ibu sebelum mendapat intervensi dengan media ebooklet adalah sebagian besar responden memiliki nilai lebih besar atau sama dengan nilai median yaitu sebanyak 20 orang $(57,1 \%)$ dan tidak ada responden yang mendapat nilai kurang dari 50. Nilai terbanyak yang diperoleh responden adalah nilai 75 yaitu sebanyak 9 orang (25,7\%). Sedangkan berdasarkan tabel 8, distribusi frekuensi tingkat pengetahuan ibu sebelum mendapat intervensi dengan media ebooklet adalah sebagian besar responden memiliki nilai lebih besar atau sama dengan nilai median yaitu sebanyak 21 orang $(60 \%)$ dan tidak ada responden yang mendapat nilai kurang dari 50. Nilai terbanyak yang diperoleh responden adalah nilai 90 yaitu sebanyak 10 orang $(28,6 \%)$.

Dari data itu bisa disimpulkan rata-rata responden mempunyai pengetahuan yang baik sebelum diberikan intervensi dan meningkat setelah diberi intervensi. Hal tersebut dibuktikan bahwa tingkat pengetahuan responden sebelum mendapatkan intervensi pendidikan kesehatan dengan media ebooklet tidak terdapat responden yang memiliki nilai pengetahuan dibawah 50 dan setelah mendapatkan intervensi pendidikan kesehatan mengalami peningkatan pengetahuan dimana nilai median 80 menjadi 90 .

Tabel 9 Efektifitas intervensi pendidikan kesehatan dengan media video terhadap tingkat pengetahuan ibu tentang pemberian MP-ASI bayi usia 6-12 bulan

\begin{tabular}{ccc}
\hline $\begin{array}{c}\text { Selisih nilai pre post test } \\
\text { media video }\end{array}$ & Frekuensi & Persentase \\
\hline-5 & 2 & 5.7 \\
\hline 0 & 4 & 11.4 \\
\hline 5 & 11 & 31.4 \\
\hline 10 & 6 & 17.1 \\
\hline 15 & 6 & 17.1 \\
\hline 25 & 3 & 8.6 \\
\hline 30 & 1 & 2.9 \\
\hline 40 & 2 & 5.7 \\
\hline Total & 35 & 100.0 \\
\hline
\end{tabular}

Pada tabel 9, dapat kita lihat bahwa tingkat pengetahuan responden setelah mendapat intervensi pendidikan kesehatan dengan media video sebagian besar 
mengalami peningkatan yaitu sebanyak 29 responden $(82,86 \%)$ sedangkan yang memperoleh nilai yang sama sebanyak 4 orang $(11,4 \%)$ dan 2 orang responden $(5,7 \%)$ mengalami penurunan nilai. peningkatan nilai terbanyak dari responden adalah 5 poin yaitu sebanyak 11 orang responden $(31,4 \%)$.

Tabel 10 Efektifitas intervensi pendidikan kesehatan dengan media ebooklet terhadap tingkat pengetahuan ibu tentang pemberian MP-ASI bayi usia $6-12$ bulan

\begin{tabular}{ccc}
\hline $\begin{array}{c}\text { Selisih nilai pre post test } \\
\text { media ebooklet }\end{array}$ & Frequency & Percent \\
\hline-10 & 1 & 2.9 \\
\hline-5 & 1 & 2.9 \\
\hline 0 & 6 & 17.1 \\
\hline 5 & 9 & 25.7 \\
\hline 10 & 9 & 25.7 \\
\hline 15 & 4 & 11.4 \\
\hline 20 & 4 & 11.4 \\
\hline 25 & 1 & 2.9 \\
\hline Total & 35 & 100.0 \\
\hline & &
\end{tabular}

Berdasarkan tabel 10, dapat kita lihat bahwa tingkat pengetahuan responden setelah mendapat intervensi pendidikan kesehatan dengan media video sebagian besar mengalami peningkatan yaitu sebanyak 27 responden (77,14\%) sedangkan yang memperoleh nilai yang sama sebanyak 6 orang $(17,1 \%)$ dan 2 orang responden $(5,7 \%)$ mengalami penurunan nilai. Peningkatan nilai terbanyak adalah 5 dan 10 poin dimana masing-masing terdapat 9 orang responden $(25,7 \%)$ yang mengalami kenaikan.

Pada tabel 9 dapat kita lihat bahwa tingkat pengetahuan responden setelah mendapat intervensi pendidikan kesehatan dengan media video sebagian besar mengalami peningkatan yaitu sebanyak 29 responden $(82,86 \%)$ sedangkan yang memperoleh nilai yang sama sebanyak 4 orang $(11,4 \%)$ dan 2 orang responden $(5,7 \%)$ mengalami penurunan nilai. Peningkatan nilai terbanyak dari responden adalah 5 poin yaitu sebanyak 11 orang responden $(31,4 \%)$.

Sedangkan pada tabel 10 dapat kita lihat bahwa tingkat pengetahuan responden setelah mendapat intervensi pendidikan kesehatan dengan media video sebagian besar mengalami peningkatan yaitu sebanyak 27 responden $(77,14 \%)$ sedangkan yang memperoleh nilai yang sama sebanyak 6 orang $(17,1 \%)$ dan 2 orang responden $(5,7 \%)$ mengalami penurunan nilai. Peningkatan nilai terbanyak adalah 5 dan 10 poin dimana masing-masing terdapat 9 orang responden $(25,7 \%)$ yang mengalami kenaikan.

Dari hasil diatas dapat disimpulkan bahwa dari kedua intervensi pendidikan kesehatan yang diberikan keduanya terbukti efektif untuk meningkatkan tingkat pengetahuan ibu tentang pemberian MP-ASI. Tetapi dilihat dari persentase responden yang mengalami peningkatan nilai, pada intervensi dengan media video mendapatkan hasil lebih banyak (82,86\%) dibandingkan dengan intervensi media ebooklet $(77,14 \%)$. Hal ini sejalan dengan hasil penelitian Winda tentang efektifitas penggunaan media leaflet, video dan buku saku untuk meningkatkan pengetahuan pemberian MPASI yang menyatakan bahwa media yang sangat efektif meningkatkan pengetahuan adalah video (Ismawati \& Kristien Andriani, 2018).

Tabel 11 Pengaruh pendidikan kesehatan dengan media video terhadap tingkat pengetahuan ibu tentang pemberian MP-ASI bayi usia $6-12$ bulan

Nilai pre test post test intervensi media video

\begin{tabular}{lrrrr}
\hline Variabel & N & $\begin{array}{c}\text { Mean } \\
\text { Rank }\end{array}$ & p-value & $\begin{array}{c}\text { Level of } \\
\text { signifikansi }\end{array}$ \\
\hline Negative & 2 & 7.00 & 0,000 & 0,05 \\
Ranks & 29 & 16.62 & & \\
Positive & 4 & & & \\
& & & & \\
\hline
\end{tabular}

Kelompok responden dengan intervensi media video pada tabel 11 sebagian besar mengalami peningkatan nilai yaitu sebanyak 29 orang responden dengan peningkatan rata rata 16,62 sedangkan 4 orang responden mendapatkan nilai yang sama dan 2 orang responden mengalami penurunan nilai. Analisa uji hubungan antara pendidikan kesehatan dengan media video terhadap pengetahuan ibu dilakukan dengan uji wilcoxon. Pada penelitian ini didapatkan hasil bahwa ada pengaruh intervensi pendidikan kesehatan dengan media video terhadap tingkat pengetahuan ibu tentang MPASI dengan nilai $p$ value 0,00 lebih kecil dari 0,05 . 
Menurut Qona kelebihan media video yaitu Media edukasi dengan video lebih direkomendasikan dalam memberikan edukasi karena penyerapan informasi lebih efektif dengan menggunakan indra pengelihatan dan pendengaran yang berupa video dibandingkan hanya menggunakan indra penglihatan saja (Sartika \& Purnanti, 2021).

Kelemahan media video adalah : film bersuara tidak dapat diselingi dengan keterangan-keterangan selagi film diputar; jalan film terlalu cepat sehingga tidak semua orang bisa mengikutinya; apa yang sudah lewat tidak dapat diputar kembali jika ada bagian yang perlu mendapat perhatian kembali (Suarioka \& Supariasa, 2012).

Berdasarkan tabel 11 dari intervensi media video sebagian besar mengalami peningkatan nilai yaitu sebanyak 29 orang responden dengan peningkatan rata rata 16,62 sedangkan 4 orang responden mendapatkan nilai yang sama dan 2 orang responden mengalami penurunan nilai. Analisa bivariat tentang pengaruh pendidikan kesehatan dengan media video terhadap peningkatan tingkat pengetahuan ibu tentang MPASI pada penelitian ini diperoleh hasil nilai $p$-value 0,000 lebih kecil dari 0,05.

Kesimpulannya pendidikan kesehatan dengan media video berpengaruh pada tingkat pengetahuan tentang MPASI pada ibu yang mempunyai bayi usia 6-12 bulan. Hasil penelitian ini sejalan dengan hasil penelitian Muninati yaitu pendidikan kesehatan melalui media audio visual dapat diterapkan dan dapat meningkatkan pengetahuan partisipan tentang pemberian MPASI pada bayi usia 6-12 bulan (Munianti \& Indrayani, 2019).

Tabel 12 Pengaruh pendidikan kesehatan dengan media ebooklet terhadap tingkat pengetahuan ibu tentang pemberian MP-ASI bayi usia $6-12$ bulan

\begin{tabular}{lrrrr}
\hline \multicolumn{4}{l}{ Nilai pre test post test intevensi media e booklet } \\
\hline Variabel & $\mathrm{N}$ & $\begin{array}{c}\text { Mean } \\
\text { Rank }\end{array}$ & $p$-value & $\begin{array}{c}\text { Level of } \\
\text { signifikansi }\end{array}$ \\
\hline Negative & 2 & 10.50 & 0,000 & 0,05 \\
Ranks & 27 & 15.53 & & \\
Positive & 6 & & & \\
& & &
\end{tabular}

Berdasarkan tabel 12, kelompok
responden dengan intervensi media ebooklet sebagian besar mengalami peningkatan nilai yaitu sebanyak 27 orang responden dengan peningkatan rata rata 15,53 sedangkan 6 orang responden mendapatkan nilai yang sama dan 2 orang responden mengalami penurunan nilai. Pada penelitian ini analisa bivariat dua kelompok berpasangan pre dan pot test intervensi dengan media ebooklet didapatkan hasil bahwa ada pengaruh intervensi pendidikan kesehatan dengan media ebooklet terhadap tingkat pengetahuan ibu tentang MPASI dengan nilai $p$ value 0,00 lebih kecil dari 0,05 .

Menurut Suariloka kelebihan Booklet yaitu dapat disimpan dalam waktu lama; sasaran dapat menyesuaikan dan belajar sendiri; pengguna dapat melihat isinya pada saat santai; dapat membantu media lain; dapat memberikan detail (misal statistik) yang tidak mungkin disampaikan secara lisan; mengurangi kegiatan mencatat; dan isi dapat dicetak kembali. Sedangkan kekurangan Booklet yaitu menuntut kemampuan baca; menuntut kemauan baca sasaran, terlebih pada masyarakat yang kebiasaan membacanya rendah (Suarioka \& Supariasa, 2012).

Berdasarkan tabel 12, dari intervensi media ebooklet sebagian besar mengalami peningkatan nilai yaitu sebanyak 27 orang responden dengan peningkatan rata rata 15,53 sedangkan 6 orang responden mendapatkan nilai yang sama dan 2 orang responden mengalami penurunan nilai. Ada pengaruh pendidikan kesehatan dengan media ebooklet terhadap peningkatan tingkat pengetahuan ibu tentang MPASI pada penelitian ini diperoleh hasil nilai p-value 0,000 lebih kecil dari 0,05.

Kesimpulannya ada pengaruh pendidikan kesehatan dengan media ebooklet terhadap tingkat pengetahuan tentang MPASI pada ibu yang mempunyai bayi usia 6-12 bulan. Hasil penelitian ini sejalan dengan Pratiwi yang menyatakan bahwa secara statistik, tidak terdapat efektivitas dalam penggunaan media booklet terhadap pengetahuan gizi seimbang pada ibu balita gizi kurang tetapi terdapat peningkatan nilai rata-rata 4,8 pada kelompok eksperimen (Pratiwi \& Puspitasari, 2017). 
Tabel 13 Efektifitas pendidikan kesehatan dengan media video dan media ebooklet

\begin{tabular}{lcc}
\hline Variabel & $p$-value & $\begin{array}{c}\text { Level of } \\
\text { signifikansi }\end{array}$ \\
\hline $\begin{array}{l}\text { Nilai post test } \\
\text { dengan media } \\
\text { video dan media } \\
\text { ebooklet }\end{array}$ & 0,629 & 0,05 \\
\hline
\end{tabular}

Dari tabel 13 analisa bivariat dua kelompok tidak berpasangan tentang efektifitas pendidikan kesehatan dengan media video dan media ebooklet dari nilai post test masing - masing intervensi diuji menggunakan uji Mann Whitney diperoleh hasil nilai $p$ value 0,629 atau lebih besar dari 0,05 yang artinya tidak ada perbedaan yang signifikan terhadap efektifitas pendidikan kesehatan antara media video dan media ebooklet.

Tabel 14 Efektifitas pendidikan kesehatan dengan media video dan media ebooklet

\begin{tabular}{lcc}
\hline Variabel & $p$-value & $\begin{array}{c}\text { Level of } \\
\text { signifikansi }\end{array}$ \\
\hline Selisih nilai pre & 0,521 & 0,05 \\
dan post test & & \\
dengan media & & \\
video dan media & & \\
ebooklet & & \\
\hline
\end{tabular}

Analisa efektifitas pendidikan kesehatan dengan media video dan media ebooklet pada table 14, dapat dianalisa berdasarkan selisih nilai post dan pre masing-masing intevensi. Efektifitas pendidikan kesehatan dengan media video dan media ebooklet dalam penelitian ini diuji menggunakan uji Mann Whitney didapatkan nilai $p$ value 0,521 atau lebih besar dari 0,05 yang artinya tidak ada perbedaan yang signifikan terhadap efektifitas pendidikan kesehatan antara media video dan media ebooklet.

Setelah dilakukan perlakuan, kedua kelompok di ukur nilai akhirnya. Berdasarkan tabel 15 , hasil mean rank nilai post test media ebooklet lebih tinggi dari media video yaitu nilai mean rank media video adalah 34,33 sedangkan untuk media ebooklet adalah 36,66. Dari hasil ini dapat disimpulkan bahwa nilai post test dengan media ebooklet mempunyai nilai rata-rata lebih tinggi dibandingkan dengan media video. Tetapi berdasarkan tabel 16, hasil mean rank dari selisih nilai pre dan post test media video lebih tinggi daripada nilai mean rank media ebooklet yaitu media video adalah 37,03 dan media ebooklet adalah 33,97. Dari hasil tersebut dapat disimpulkan bahwa hasil mean rank selisih nilai pretest post test media video lebih tinggi dari media ebooklet.

Tabel 15 Tingkat pengetahuan setelah diberikan pendidikan kesehatan dengan media video dan media ebooklet

\begin{tabular}{lccc}
\hline \multicolumn{1}{c}{ Variabel } & N & $\begin{array}{c}\text { Mean } \\
\text { Rank }\end{array}$ & $\begin{array}{c}\text { Sum of } \\
\text { Ranks }\end{array}$ \\
\hline $\begin{array}{l}\text { Nilai post test } \\
\text { intervensi media } \\
\text { video }\end{array}$ & 35 & 34.34 & 1202.00 \\
$\begin{array}{l}\text { Nilai post test } \\
\text { intervensi media } \\
\text { ebooklet }\end{array}$ & 35 & 36.66 & 1283.00 \\
Total & 70 & & \\
\hline
\end{tabular}

Tabel 16 Peningkatan pengetahuan setelah diberikan pendidikan kesehatan dengan media video dan media ebooklet

\begin{tabular}{lccc}
\hline \multicolumn{1}{c}{ Variabel } & $\mathrm{N}$ & $\begin{array}{c}\text { Mean } \\
\text { Rank }\end{array}$ & $\begin{array}{c}\text { Sum of } \\
\text { Ranks }\end{array}$ \\
\hline $\begin{array}{l}\text { Selisih nilai pre post } \\
\text { test media video }\end{array}$ & 35 & 37.03 & 1296.00 \\
$\begin{array}{l}\text { Selisih nilai pre post } \\
\text { test media ebooklet }\end{array}$ & 35 & 33.97 & 1189.00 \\
Total & 70 & & \\
\hline
\end{tabular}

Berdasarkan tabel 15, hasil mean rank nilai post test media ebooklet lebih tinggi dari media video yaitu nilai mean rank media video adalah 34,33 sedangkan untuk media ebooklet adalah 36,66. Dari hasil ini dapat disimpulkan bahwa nilai post test dengan media ebooklet mempunyai nilai rata-rata lebih tinggi dibandingkan dengan media video. Tetapi berdasarkan tabel 16, hasil mean rank dari selisih nilai pre dan post test media video lebih tinggi daripada nilai mean rank media ebooklet yaitu media video adalah 37,03 dan media ebooklet adalah 33,97 . Dari hasil tersebut dapat disimpulkan mean rank selisih nilai pretest post test media video lebih tinggi dari media ebooklet.

Media termasuk salah satu faktor yang meningkatkan efektifitas proses pembelajaran, karena secara langsung maupun tidak langsung media pembelajaran meningkatkan minat dan atensi sasaran dalam menerima materi. Dengan media yang tepat, jelas dan menarik maka peserta 
akan lebih tertarik pada materi yang disampaikan dan lebih mudah memahaminya.

Penggunaan media pendidikan bermanfaat untuk menarik perhatian sasaran, memperjelas pesan yang disampaikan hingga mengingatkan kembali pesan yang telah disampaikan oleh narasumber. Menurut Edgar Dale penggunaan media belajar seringkali menggunakan prinsip kerucut pengalaman yang membutuhkan media belajar seperti buku teks, bahan belajar yang dibuat oleh pengajar serta audio visual. Sumber lain mengatakan bahwa efektifitas media terhadap pemahaman sasaran adalah: secara verbal: $1 \mathrm{x}$, secara visual: $3,5 \mathrm{x}$, secara audio visual: $6 \times$ (Susilowati, 2016).

Untuk menguji perbedaan efektifitas pendidikan kesehatan dengan media video dan media ebooklet analisa dua kelompok tidak berpasangan, peneliti menggunakan uji Mann Whitney karena data berdistribusi tidak normal. Uji efektifitas berdasarkan nilai post test masing-masing intervensi yang dilakukan didapatkan hasil $p$-value 0,629 atau lebih besar dari nilai signifikansi 0,05 dan berdasarkan selisih nilai pre dan post test masing-masing intervensi diperoleh hasil nilai $p$-value 0,521 atau lebih besar dari 0,05 yang artinya tidak ada perbedaan yang signifikan terhadap efektifitas pendidikan kesehatan dengan media video dan media ebooklet. Hasil penelitian ini sejalan dengan hasil penelitian sebelumnya yang meyatakan bahwa tidak ada pengaruh yang signifikan antara rata-rata pengetahuan responden dari media leaflet, video dan buku saku dengan nilai $p=0,103$ (Ismawati \& Kristien Andriani, 2018).

Berdasarkan tabel 15 , hasil mean rank nilai post test media ebooklet lebih tinggi dari media video yaitu mean rank media video adalah 34,33 sedangkan untuk media ebooklet adalah 36,66 . Dari hasil ini dapat disimpulkan bahwa nilai post test dengan media ebooklet mempunyai nilai rata-rata lebih tinggi dibandingkan dengan media video. Tetapi berdasarkan tabel 1.16 hasil mean rank dari selisih nilai pre dan post test, nilai mean rank media video lebih tinggi dari media ebooklet yaitu nilai mean rank media video adalah 37,03 dan media ebooklet adalah 33,97. Dari hasil tersebut dapat disimpulkan bahwa hasil mean rank selisih nilai pre dan post test dengan media video lebih tinggi dari media ebooklet yang artinya meskipun tidak ada perbedaan efektifitas yang signifikan, pendidikan kesehatan dengan media video lebih efektif dibandingkan media ebooklet. Hal ini sejalan dengan hasil penelitian Winda tentang efektifitas penggunaan media leaflet, video dan buku saku untuk meningkatkan pengetahuan pemberian MPASI yang menyatakan bahwa media yang paling efektif menigkatkan pengetahuan adalah media video (Ismawati \& Kristien Andriani, 2018).

\section{Kesimpulan}

Ada pengaruh pendidikan kesehatan terhadap tingkat pengetahuan ibu tentang MPASI sebelum dan sesudah diberikan pendidikan kesehatan melalui media video dengan nilai $p$-value 0,000 lebih kecil dari 0,05 . Ada pengaruh pendidikan kesehatan terhadap tingkat pengetahuan ibu tentang MPASI sebelum dan sesudah diberikan pendidikan kesehatan melalui media ebooklet dengan nilai p-value 0,000 lebih kecil dari 0,05. Namun demikian tidak ada perbedaan yang signifikan tentang efektifitas media video dengan media ebooklet dalam peningkatan pengetahuan ibu tentang MPASI. Sebaiknya pemberian pendidikan kesehatan tentang MP ASI dapat dilakukan secara rutin agar ibu-ibu lebih paham dan mengerti tentang MP ASI serta dapat dipraktikan di rumah dan sebaiknya pemberian pendidikan kesehatan bagi masyarakat disertai dengan alat bantu seperti video maupun ebooklet.

\section{Ucapan Terima Kasih}

Penulis tidak dapat menyelesaikan penelitian ini tanpa bantuan dari berbagai pihak. Untuk itu penulis menyampaikan ucapan terimakasih yang tulus kepada : Direktur Poltekkes Kemenkes Semarang, Ketua Perwakilan Jurusan Kebidanan Magelang Poltekkes Kemenkes Semarang, Ketua Prodi Sarjana Terapan Kebidanan Magelang Poltekkes Kemenkes Semarang, Dosen Pembimbing dan Penguji, Segenap Dosen Staf Pengajar dan Karyawan Prodi Sarjana Terapan Kebidanan Magelang Magelang Poltekkes Kemenkes Semarang, 
Bapak dan lbu, Semua pihak yang tidak dapat disebutkan satu-satu yang telah banyak membantu dalam penyusunan penelitian ini..

\section{Daftar Pustaka}

Ahmadi, F., \& Ibda, H. (2018). Media Literasi Sekolah Teori dan Praktek (D. M. Wijayanti (ed.); 2nd ed.). CV. Pilar Nusantara.

Dinas Kesehatan Kota Magelang. (2020). Profil Kesehatan Kota Magelang tahun 2020.

Ismawati, W., \& Kristien Andriani, S. K. M. (2018). Efektifitas Penggunaan Media Leaflet, Buku Saku, Video untuk meningkatkan Pengetahuan Pemberian Makanan Pendamping Air Susu Ibu (MP ASI) Di Desa Kenep Kecamatan Sukoharjo. Universitas Muhammadiyah Surakarta.

Kementrian Kesehatan RI. (2020). Peraturan Menteri Kesehatan Republik Indonesia Nomor: 2 tahun 2020 tentang Standar Antropometri Anak. Kementrian Kesehatan RI.

Muharram, I., Faradillah, A., Helvian, F. A., Sari, J. I., \& Sabri, M. S. (2021). PENGARUH EDUKASI MP-ASI TERHADAP PENINGKATAN PENGETAHUAN IBU. Ibnu Sina: Jurnal Kedokteran Dan Kesehatan-Fakultas Kedokteran Universitas Islam Sumatera Utara, 20(2), 76-90.
Munianti, Y., \& Indrayani, E. (2019). Penerapan Pendidikan Kesehatan melalui Media Audio Visual untuk Meningkatkan Pengetahuan lbu tentang Pemberian Makanan Pendamping ASI pada Bayi Usia 6-12 Bulan. Proceeding of The URECOL, 380-385.

Pratiwi, Y. F., \& Puspitasari, D. I. (2017). Efektivitas penggunaan media booklet terhadap pengetahuan gizi seimbang pada ibu balita gizi kurang di kelurahan semanggi kecamatan pasar kliwon kota surakarta. Jurnal Kesehatan, 10(1), 58-67.

Sartika, Q. L., \& Purnanti, K. D. (2021). PERBEDAAN MEDIA EDUKASI (BOOKLET DAN VIDEO) TERHADAP KETRAMPILAN KADER DALAM DETEKSI DINI STUNTING. Jurnal Sains Kebidanan, 3(1), 36-42.

Suarioka, I. P., \& Supariasa, I. D. N. (2012). Media Pendidikan Kesehatan. Graha IImu.

Susilowati, D. (2016). Promosi Kesehatan (Kemenkes RI (ed.); 1st ed.). Kemenkes RI. 